Rhizobial inoculation improves drought tolerance, biomass and grain yields of common bean (Phaseolus vulgaris L.) and soybean (Glycine max L.) at Halaba and Boricha in Southern Ethiopia

\title{
Aserse, Aregu
}

2020-03-20

Aserse , A , Markos , D , Getachew , G, Yli-Halla , M \& Lindström , K 2020 , ' Rhizobial inoculation improves drought tolerance, biomass and grain yields of common bean (Phaseolus vulgaris L.) and soybean (Glycine max L.) at Halaba and Boricha in Southern Ethiopia ' , Archives of Agronomy and Soil Science , vol. 66 , no. 4 , pp. 488-501 . https://doi.org/10.1080/03650340.

http://hdl.handle.net/10138/315756

https://doi.org/10.1080/03650340.2019.1624724

acceptedVersion

Downloaded from Helda, University of Helsinki institutional repository.

This is an electronic reprint of the original article.

This reprint may differ from the original in pagination and typographic detail.

Please cite the original version. 

bean (Phaseolus vulgaris L.) and soybean (Glycine max L.) at Halaba and Boricha in

\section{Southern Ethiopia}

4

Aregu Amsalu Aserse ${ }^{\mathrm{a}}$, Daniel Markos ${ }^{\mathrm{b}}$, Genet Getachew ${ }^{\mathrm{b}}$, Markku Yli-Halla ${ }^{\mathrm{c}}$, Kristina

Lindström $^{\mathrm{a}}$

7

${ }^{\text {a} E c o s y s t e m s ~ a n d ~ E n v i r o n m e n t ~ R e s e a r c h ~ P r o g r a m m e, ~ F a c u l t y ~ o f ~ B i o l o g i c a l ~ a n d ~ E n v i r o n m e n t a l ~}$

Sciences and Helsinki Institute of Sustainability Science (HELSUS), Helsinki, Finland;

${ }^{\mathrm{b}}$ Southern Agricultural Research Institute, Hawassa, Ethiopia; ${ }^{\mathrm{c} D e p a r t m e n t ~ o f ~ A g r i c u l t u r a l ~}$

11 Sciences, University of Helsinki, Finland;

12

CONTACT: Aregu Amsalu Aserse; Ecosystems and Environment Research Programme,

Faculty of Biological and Environmental Sciences and Helsinki Institute of Sustainability

Science (HELSUS), Helsinki, Finland; Email: aregu.aserse@ helsinki.fi

16

\section{Abstract}

While pulses are staple food-legumes in Ethiopia, their productivity is low due to low soil fertility. Elite rhizobial strains that significantly increased shoot dry weight and nitrogen $(\mathrm{N})$ contents of common beans and soybeans in greenhouse were selected for two-year field trials to evaluate their effect on yields of the pulses in the field. Each pulse had six treatments, namely four rhizobial inoculants, uninoculated control and synthetic $\mathrm{N}$ fertilizer. In the droughtaffected year 2015, inoculated pulses tolerated moisture stress better than non-inoculated controls. Inoculation was conducive to higher or equivalent yields compared to synthetic $\mathrm{N}$ fertilizer. At Halaba, bean inoculated with strain HAMBI3562 gave the highest grain yield $\left(1500 \pm 81 \mathrm{~kg} \mathrm{ha}^{-1}\right.$; mean \pm SE) while the control yielded only $653 \pm 22 \mathrm{~kg} \mathrm{ha}^{-1}$. At Boricha, 
HAMBI3570 gave a grain yield $\left(640 \pm 35 \mathrm{~kg} \mathrm{ha}^{-1}\right)$ comparable to synthetic $\mathrm{N}$. When rainfall was optimal in 2016, inoculation with HAMBI3562 and HAMBI3570 gave grain yields (around $4300 \mathrm{~kg} \mathrm{ha}^{-1}$ ) equivalent to synthetic N. With soybean, strain HAMBI3513 produced consistently higher or comparable biomass and grain yields compared to synthetic N. In conclusion, HAMBI3562 and HAMBI3570 for beans and HAMBI3513 for soybeans can serve as inoculants for areas having similar conditions as the test areas.

Keywords: biological nitrogen fixation; Rhizobium strains; Bradyrhizobium strains; pulses; food security

\section{Introduction}

Food security is a major issue in many African countries (WFP 2018). Ethiopia, with the second largest population in Africa, about 105 million (UNDP 2018), is one of the world's food insecure countries. Ethiopian economy is fundamentally dependent on agriculture. This sector accounts for $50 \%$ of the GDP, over $80 \%$ of exports and about $80 \%$ of the labor force. Smallholder farms are the pillars of the agriculture sector, and cover about $95 \%$ of the cultivated area and $90 \%$ of the total production (Welteji 2018). However, the farming practices are characterized by low yield per unit area, mainly due to poor soil fertility of the farmlands and poor farm management practices, soil erosion, land degradation, and lack of nutrient inputs (Tesfa and Mekuriaw 2014; Fadong et al. 2018). In addition, susceptibility of the country to drought and climate change effects are becoming major challenges for food production and food security.

In Ethiopia, food legumes (pulses) are an integral part of the staple foods for the society. Common bean (Phaseolus vulgaris L.) is one of the most important food legumes in Africa and Latin America. This pulse is widely cultivated for food consumption and is also the third export commodity after coffee and sesame (Katungi et al. 2010). It is largely cultivated by smallholder farmers in the Rift Valley area, and in the southeastern and southwestern parts 
of the country, as a sole crop or intercropped with non-legumes, such as maize, sorghum, enset, and coffee (Katungi et al. 2010; Abebe 2017; Assefa et al. 2017). The land coverage and production of common bean in the country is increasing over time. Nevertheless, there is a huge yield gap, as its productivity in the farmers' field remains low compared to the yields obtained in the research fields. For instance, the national average yield reported in the cropping seasons of 2011/12 and 2015/16 was $1169 \mathrm{~kg} \mathrm{ha}^{-1}$ and $1485 \mathrm{~kg} \mathrm{ha}^{-1}$, respectively (Cochrane and Bekele 2018). These values were below the potential yield range $2000-3084 \mathrm{~kg} \mathrm{ha}^{-1}$ obtained at research stations (Emishaw 2007; Asfaw et al. 2008).

Soybean (Glycine max L.) is produced worldwide for its high food and feed values (Sinclair et al. 2014). USA, Brazil, Argentina, China, India, Paraguay, and Canada are the leading soybean producing countries in the world (https://www.statista.com/statistics/263926/soybean-production-in-selected-countries-since1980/). Soybean has been introduced to Ethiopia from the 1950s (Belay 1987). The major soybean growing regions are found in the southern and western parts of the country. In these regions, the smallholder as well as large-scale farmers produce soybean mainly for cash and food, and sometimes for improvement of soil fertility by rotations with cereals. A case study in northwestern Ethiopia, Metekel Zone, shows that about $90 \%$ of soybean produced in this region is used for income generating purposes and only a small portion is used for food by the farmers (Getahun and Tefera 2017). The yield of soybean in smallholder farmers' field was on average $1633 \mathrm{~kg} \mathrm{ha}^{-1}$ in 2012 and $1814 \mathrm{~kg} \mathrm{ha}^{-1}$ in 2013, which were below the corresponding yields 3175 and $2359 \mathrm{~kg} \mathrm{ha}^{-1}$ obtained in research fields in respective years (MARD 2013). According to a research conducted in farmers' field, soybean yields were found to vary from less than $1000 \mathrm{~kg}$ $\mathrm{ha}^{-1}$ to about $6000 \mathrm{~kg} \mathrm{ha}^{-1}$ depending on soil characteristics of the farm fields (Zerihun et al. 2015). to lack of improved or locally adaptive varieties, poor farming systems, moisture stress, low 
soil fertility, diseases and insect pests (Katungi et al. 2010; Darkwa et al. 2016). The low soil fertility of the farmlands; i.e. deficiency of organic matter and the major plant growth limiting nutrients $\mathrm{N}$ and phosphorus $(\mathrm{P})$ in soils and lack of nutrient inputs were reported as the main factors contributing to the low yields and productivities of the pulses (Abebe 2017; Zerihun and Haile 2017).

Pulses, such as common bean and soybean make a $\mathrm{N}_{2}$-fixing symbiotic association with soil bacteria commonly known as rhizobia. Biological nitrogen fixation (BNF) by the legumes in symbiosis with rhizobia fulfills the $\mathrm{N}$ requirements needed for the plant growth and consequently, increases biomass and yield of the legume crops without application of synthetic $\mathrm{N}$ fertilizers to the soil. In addition, litter-fall and residual decomposition of the legumes improve the $\mathrm{N}$ and organic $\mathrm{C}$ contents of the soils, which in turn benefit the sustainability of the soil fertility and enhance subsequent cereal production cultivated in rotation with legumes (Bado et al. 2013; Zerihun and Haile 2017). Thus, for yield increase, inoculation of pulses with selected superior rhizobia is feasible, instead of applying synthetic fertilizer, which is neither an alternative for poor farmers nor for sustainable food production. Common bean- and soybean-nodulating rhizobial strains were isolated in Ethiopia and characterized previously (Aserse et al. 2012a, 2012b). The first objective of this study was to test and select effective $\mathrm{N}_{2}$-fixing rhizobia symbionts for bean and soybean, based on their symbiotic performance on host plants in greenhouse conditions. The second objective of the work was to evaluate the effect of selected rhizobial inoculants on growth, biomass and grain yield of beans and soybeans in the field conditions at Halaba and Boricha sites in southern Ethiopia for two consecutive growing seasons. 
Nodulation and symbiotic efficiency test in the greenhouse

107

108

109

110

Rhizobial strains isolated from root nodules of bean and soybean plants grown in the field in Ethiopia were previously described and tested for nodulation and $\mathrm{N}_{2}$ fixation efficiency under controlled conditions in plant growth chambers (Aserse et al. 2012a, 2012b). Based on preliminary nodulation and symbiotic performance, sixteen bean- and nine soybean-nodulating rhizobial strains were selected to assess their symbiotic effectiveness in soil culture under greenhouse conditions and to select the best strains for the field experiments (Table 1). The test was conducted at the Viikki campus greenhouse facility of the University of Helsinki, Finland. The seeds were planted in plastic pots with the dimensions of $16 \mathrm{~cm}$ diameter and $18 \mathrm{~cm}$ depth, filled with 2.51 of potting soil containing a low $\mathrm{N}$ content. The soil properties were as follows: $\mathrm{pH}\left(\mathrm{H}_{2} \mathrm{O}\right) 6.5$, electrical conductivity (EC) $20 \mathrm{mS} \mathrm{m}^{-1}$, soluble $\mathrm{N} 50 \mathrm{mg} \mathrm{l}^{-1}, \mathrm{~K}^{2} 200 \mathrm{mg} \mathrm{l}^{-1}$, P 60 $\mathrm{mg} \mathrm{l}^{-1}$ and bulk density $510 \mathrm{~g} \mathrm{l}^{-1} . \mathrm{P}$ and $\mathrm{K}$ were extracted with $0.01 \mathrm{M} \mathrm{CaCl}_{2}-0.002 \mathrm{M}$ DTPA solution (Finnish Standards Association 2002a) and N with deionized water (Finnish Standards Association 2002b). The potting soil was purchased from a greenhouse supplies company Kekkilä Oy, Mellilä, Finland.

\section{[Table 1 near here]}

The treatments (rhizobial strains) were replicated into three pots in randomized complete design form and four seeds were planted in each pot. Ethiopian common bean variety red wolayta and soybean local cultivar 1 were used for this experiment. The seeds were sterilized with $95 \%$ alcohol followed by 3-5\% sodium hypochlorite and rinsed with several changes of sterile water (Somasegaran and Hoben 1994). The strains were grown in Yeast Extract Mannitol (YEM) broth as described previously (Aserse et al. 2012a, 2012b). In the day of planting of the seeds, $1 \mathrm{ml}$ suspension of the rhizobial strains (about $10^{8} 1^{-1}$ cells) was added on each seed, except for the control treatments that received no rhizobia inoculant. Plants were watered twice a week with tap water with an irrigation system and grown at $28 \pm 2{ }^{\circ} \mathrm{C}$ day and $18{ }^{\circ} \mathrm{C}$ nighttime 
131 temperature, and a $16 \mathrm{~h}$ day and $8 \mathrm{~h}$ night cycle. The plants were harvested after 6 weeks and

132 the plant appearance, nodule number, and nodule color data were recorded. Plant shoots

133 (including all above ground plant parts) were oven-dried at $70{ }^{\circ} \mathrm{C}$ for $24 \mathrm{~h}$, dry matter weighed,

134 ground and analyzed for $\mathrm{N}$ and $\mathrm{C}$ concentrations using the VarioMax dry combusting

135 instrument. The $\mathrm{N}$ and $\mathrm{C}$ contents were calculated as the product of total shoot dry matter of a

136 plant and the respective $\mathrm{C}$ and $\mathrm{N}$ concentrations in the shoot. The SPSS statistical package was

137 used to analysis the data and means between treatments were compared by the least significant

138 difference (LSD) test $(\mathrm{p} \leq 0.05)$.

\section{Field experiments}

140 Description of experimental sites and soil properties

141 The field experiments were carried out at two sites in Halaba and Boricha districts in southern

142 Ethiopia for two growing seasons in 2015 and 2016. The Halaba site is located at $07^{\circ} 19.04^{\prime}$

143 North and $038^{\circ} 04.9^{\prime}$ East with an altitude of $1650 \mathrm{~m}$ above sea level. The Boricha site is located

144 at $06^{\circ} 54.9^{\prime}$ North and $038^{\circ} 20.4^{\prime}$ East and at the altitude of $1620 \mathrm{~m}$ above sea level. Based on

145 the long-term national weather data, the annual mean rainfall of the Halaba and Boricha districts

146 were $857-1085 \mathrm{~mm}$ and $500-1242 \mathrm{~mm}$, respectively, and annual temperature varied from 17

147 to $25^{\circ} \mathrm{C}$ in Halaba and $18-29^{\circ} \mathrm{C}$ in Boricha district (Ganewo 2017; Tarfasa et al. 2018 ).

148 Southern Ethiopia including in Halaba and Boricha has a bimodal rainfall pattern with a short

149 rainy season that lasts from March to May, while a longer rainy main growing season takes

150 place from July to October (Tarfasa et al. 2018). The field experiments were carried out during

151 the main growing season (July - October) at both sites for two years. The rainfall received and

152 its distribution in 2016 during the plant growth period was better than in 2015 . There was a

153 strong drought in 2015 due to the El Niño episode and this year the rainfall in large part of

154 Ethiopia was below-normal during the growing season (July-September) (AKLDP 2015; Philip

155 et al. 2018). Our field experiments were affected by the drought and moisture stress in 2015. 
157 mays), teff (Eragrostis tef), hot pepper (Capsicum frutescence), wheat (Triticum spp.) and beans

158 (Tarfasa et al. 2018). There had not been a history of soybean and bean rhizobia inoculation

159 before the experiment at the particular sites. Both in 2015 and 2016, bean and soybean trials at

160 Halaba site were taking place in the fields, where wheat was grown the other year. At Boricha

161 site, prior to the pulse trials in 2015 and 2016, the fields were planted with maize and wheat

162 respectively.

Composite soil samples of $0-30 \mathrm{~cm}$ and $30-50 \mathrm{~cm}$ depths were collected on 8

164

165

166

167

168

169

170

171

172

174

October, 2015 and analyzed for physico-chemical characteristics characteristics mainly according to van Reeuwijk (2002). Particle size distribution was determined with a pipette method after digestion with $\mathrm{H}_{2} \mathrm{O}_{2}$ and $\mathrm{HCl}$ and dispersion with $\mathrm{K}_{4} \mathrm{P}_{2} \mathrm{O}_{7}$. Soil $\mathrm{pH}$ and EC were measured in 1:2:5 soil/water (v/v) suspension. Total $\mathrm{C}$ and $\mathrm{N}$ were determined by dry combustion, while soluble $\mathrm{P}$ was extracted by the Olsen method (0.5 $\mathrm{M} \mathrm{NaHCO}_{3}$ at $\left.\mathrm{pH} 8.5\right)$. Exchangeable $\mathrm{Ca}, \mathrm{Mg}, \mathrm{K}, \mathrm{Na}$ and titratable acidity were extracted with $1 \mathrm{M}$ ammonium acetate buffered at $\mathrm{pH} 7$, and all results of cations were expressed as $\mathrm{cmol}(+) \mathrm{kg}^{-1}$. Potential cation exchange capacity $\left(\mathrm{CEC}_{\mathrm{pot}}\right)$ and base saturation (BS) were calculated as $\mathrm{Ca}+\mathrm{Mg}+\mathrm{K}+\mathrm{Na}+$ titratable acidity and $\mathrm{BS}=100 \times(\mathrm{Ca}+\mathrm{Mg}+\mathrm{K}+\mathrm{Na}) / \mathrm{CEC}_{\mathrm{pot}}$, respectively. Both experimental sites consisted of a loamy soil with practically similar percentages of clay, sand and silt (Table 2). The soils were non-saline, and they contained no sodicity. The $\mathrm{pH}\left(\mathrm{H}_{2} \mathrm{O}\right)$ in the topsoil was about 8.0 at Halaba and 6.4 at Boricha. Accordingly, there was no exchangeable Al, and the base saturation was high at both sites, the exchange sites being mostly occupied by $\mathrm{Ca}$. The content of soil organic matter $\left(1.732 \times \mathrm{C}_{\mathrm{tot}}\right)$ was $2.5 \%$ at Halaba and $3.1 \%$ at Boricha. Plant available P was very low at Halaba and at the borderline of low and very low at Boricha. According to the World Reference Base for Soil Resources (FAO 2014), the Halaba soil was classified as an Eutric Fluvisol (Loamic) and the Boricha soil as a Mollic Andosol (Loamic). 
183 Experimental design, treatments and field management

184 The experiments were arranged in Randomized Complete Block Design in three replications.

185 There were six treatments for each of bean and soybean experiments including two non186 inoculated controls, i.e. treatment without $\mathrm{N}$ source as a negative control and plots fertilized 187 with urea $\left(46 \mathrm{~kg} \mathrm{ha}^{-1} \mathrm{~N}\right)$ as a N source. All the six treatments received Triple Superphosphate 188 (TSP) $\left(20 \mathrm{~kg} \mathrm{ha}^{-1} \mathrm{P}\right)$ uniformly. For the bean, the rhizobial treatments were strains Rhizobium etli HAMBI3556 (HBR5), Rhizobium phaseoli HAMBI3562 (HBR10), R. phaseoli HAMBI3570 (HBR53) and rhizobial strain EAL428. For soybean, Bradyrhizobium japonicum HAMBI3524, Bradyrhizobium elkanii HAMBI3513 (SBR2B), B. elkanii HAMBI3520 (SBR8B) and rhizobial strain LF were used as inoculant treatments. Except the commercial

193 inoculants EAL428 and LF that were used as references, all the others were characterized and stored in the HAMBI culture collections of the University of Helsinki (Aserse et al. 2012a, 2012b). B. japonicum strains HAMBI3524, also known by the strain code USDA136 (TAL 379) was first obtained from the NifTAL culture collection in Hawaii, USA and has been used as an inoculant strain for soybean in Ethiopia (Aserse et al. 2012a). The commercial inoculants

198 EAL428 and LF were obtained from the local inoculant company Menagesha PLC in Ethiopia. The HAMBI strains were selected for the field experiment based on their effective $\mathrm{N}_{2}$ fixation performance in the greenhouse experiment. The rhizobial inoculants with peat as the carrier material were prepared by the Finnish inoculant producing company Elomestari Ltd. ploughing three times with oxen drawn implements. Local common bean variety HawasaDume and soybean variety Hawasa-95 were used for the field trials. Before sowing, the seeds were soaked with tap water until the seed coat became rough and suitable for the inoculants to adhere to the seeds. Then, seeds for the plots receiving inoculants were dressed separately with 
immediately prior to planting. To avoid cross-inoculation we followed all the necessary aseptic

209 instructions as described in Somasegaran and Hoben (1994). Planting was done manually in

210 July. The plot size, number of rows and seed spacing were the same for both bean and soybean

211 experiments. Each plot had a $2 \mathrm{~m} \times 3 \mathrm{~m}$ size and 5 rows. The seeds were sown at row - to- row

212 distance of $40 \mathrm{~cm}$ and with $10 \mathrm{~cm}$ spacing between plants. The two outside rows were assigned

213 as border rows whereas the remaining three central rows formed the net plot area. One of these

214 was used as sampling row and the remaining rows were used for yield component estimation.

215 Plant sampling, harvesting and analyses

216 Three plants were randomly collected at mid-flowering stage from sampling rows for nodule

217 number counting. Plant height $(\mathrm{cm})$ was measured from five randomly taken plants of each net

218 plot at $90 \%$ physiological maturity with a standard meter ruler. Number of pods per plant were

219 counted from 20 randomly taken plants in the rows within the net plot area at harvest maturity

220 and the means were reported as number of pods per plant. Average number of seeds per pod

221 was inferred from the total numbers of seeds dividing by the total number of pods. All plants

222 from the net plot area were harvested and sun-dried until a constant dry weight was attained,

223 followed by determination of above ground biomass. After threshing and cleaning, the seed

224 yield was adjusted to a moisture level of $10 \%$. Hundred seed weight (g) was measured by

225 weighing 100 randomly taken seeds from the harvested yield using an electronic weighing

226 balance. Finally, the biomass and yield per plot was converted to hectare basis and reported as

227 kilogram per hectare. Analysis of variance was carried out for the collected data using the SPSS

228 statistical package with application of the $\mathrm{F}$ test $(\mathrm{p} \leq 0.05)$. A three-factor analysis of variance

229 (ANOVA) was performed to evaluate the effects of treatments (synthetic N, rhizobial

230 inoculations), locations and years and their interactions on grain yield and other yield

231 components. Mean differences between treatments were compared by the least significant

232 differences (LSD) test $(\mathrm{p} \leq 0.05)$. 


\section{Symbiotic efficiency of rhizobial strains in the greenhouse}

236 All the rhizobial strains listed in Table 1 nodulated their respective bean and soybean host plants and nodules were pink (except the bean inoculated with HAMBI3549), showing the effectiveness of the symbiosis. Inoculated plants looked healthy, the leaves were dark green, and plants grew better compared to the non-inoculated counterparts. The non-inoculated control

240 plants did not produce nodules (data not shown). The symbiotic $\mathrm{N}_{2}$ fixation effectiveness was 241 deduced from the plant shoot dry weight (SDW) and plant $\mathrm{N}$ contents. The SDW and total $\mathrm{N}$ 242 content of the common bean and soybean plants inoculated with the rhizobial strains increased 243 significantly compared with the non-inoculated control treatment (Table 1). Beans inoculated 244 with strains HAMBI3562, HAMBI3565, HAMBI3570, HAMBI3556 and HAMBI3573 245 performed well, providing about $19-18 \mathrm{~g} \mathrm{SDWs}$ and $0.47-0.44 \mathrm{~g} \mathrm{~N}$ contents per plant, the 246 increases being $9-10 \mathrm{~g}$ SWDs and about $0.3 \mathrm{~g} \mathrm{~N}$ per plant over the non-inoculated control. 247 Soybean plant inoculated with strain HAMBI3524 provided the highest plant N content $(0.42$ $248 \mathrm{~g}$ per plant). The soybeans inoculated by the strains HAMBI3520, HAMBI3524 and 249 HAMBI3513 were among the best performing plants with regard to of SDW. Considering the 250 strains performance in terms of the plant N content and/or SDW in greenhouse tests, the bean 251 strains (HAMBI3562, HAMBI3570, HAMBI3556) and soybean strains (HAMBI3524, 252 HAMBI3513, HAMBI3520) were selected for field trials (Table 1).

\section{Field trial results}

254 The field trials were performed for two consecutive years at two sites, in Halaba and Boricha. 255 In 2015, the fields suffered from bad drought, whereas in 2016 rainfall was normal. The mean 256 yield components for bean and soybean field results are presented in Tables 3 and 4. Bacterial 257 inoculations increased plant growth parameters depending on the strain. The overall mean yield 258 components were significantly $(\mathrm{p} \leq 0.05)$ different between the experimental locations, 259 treatments, years and/or between the interactions of the factors. The effect of year, location 
and/or their interaction were highly significant and strong regarding the growth and yield 261 parameters of the pulses, particularly for nodule numbers, biomass and grain yield (Table 3 and 4).

The yield difference between years was associated with the difference in the moisture content of the field sites. In 2015, the rainfall distribution was very variable, sporadic and erratic during the plant growth period and at the flowering stage on our experimental sites, which resulted in moisture stress and yield reduction of the pulses. In fact the drought in 2015 caused by El Nino was a major cause of crop yield reduction in Ethiopia (AKLDP 2015; Philip et al. 2018). The drought stress of 2015 was manifested more at the Boricha than at Halaba. Thus, the mean nodule number, biomass and grain yields of the beans were two-fold or higher at Halaba compared with Borcha and the means of the main yield components of soybean were significantly higher at Halaba than at Boricha. However, there was no significant difference in the plant height, seeds per pod, pods per plant and/or hundred seed weight data of the pulses between the sites.

In 2016, when there was more moisture for the plant growth, the overall yield components of the beans were comparable between the sites. The soybean mean nodule numbers and biomass yields were higher at Halaba, but on the other hand, the grain yield and pods per plant were greater at Boricha. In that year, there was no significant difference in plant height, seeds per pod, and hundred seed weight of soybeans between the two sites (data not 279 shown).

As the effect of treatments on the main yield components was varied depending 281 on the sites and/or years, independent comparison of biomass and grain yields was made between treatments for each location and year (Tables 3 and 4). Generally, when the field sites were severely affected by drought, inoculation successfully helped the plants to adapt to and tolerate the moisture stress. Inoculation with at least one of the bean rhizobial strains and three of the soybean inoculants resulted in higher or equivalent biomass and grain yields compared 
to the pulses receiving synthetic $\mathrm{N}$ fertilizer. The lowest bean and soybean biomass and grain

287 yields were recorded from plots that received neither synthetic $\mathrm{N}$ fertilizer nor the rhizobial inoculants, known as "non-inoculated control" hereafter (Tables 3 and 4). The non-inoculated control yields of the beans were substantially affected by the different water supplies, grain yields being only $140-650 \mathrm{~kg} \mathrm{ha}^{-1}$ in 2015 and as much as $2800-3600 \mathrm{~kg} \mathrm{ha}^{-1}$ in 2016.

At Halaba, under the drought stress in 2015, the bean inoculated with

HAMBI3562 delivered the highest biomass yield $\left(3013 \pm 355 \mathrm{~kg} \mathrm{ha}^{-1}\right)$ as well as grain yield $\left(1500 \pm 81 \mathrm{~kg} \mathrm{ha}^{-1}\right)$. At Borchia, the biomass and grain yields obtained from bean inoculated with strain HAMBI3570 and bean receiving synthetic $\mathrm{N}$ were comparable, with strain HAMBI3570 giving $1240 \pm 788 \mathrm{~kg} \mathrm{ha}^{-1}$ biomass and $640 \pm 35 \mathrm{~kg} \mathrm{ha}^{-1}$ grain yields. Increase of grain yield, compared to the non-inoculated bean without synthetic $\mathrm{N}$ fertilization was 500 and $870 \mathrm{~kg} \mathrm{ha}^{-1}$ for HAMBI3570 and HAMBI3562, respectively.

In 2016, at Halaba site, generally the biomass and/or grain yields of inoculated

beans were comparable to the bean receiving synthetic $\mathrm{N}$, but higher compared to the control plot. The biomass and grain yields obtained from bean inoculated with strain HAMBI3562 were $7022 \pm 130 \mathrm{~kg} \mathrm{ha}^{-1}$ and $4360 \pm 81 \mathrm{~kg} \mathrm{ha}^{-1}$, respectively. Inoculation with the HAMBI strains increased bean grain yields by $500-1800 \mathrm{~kg} \mathrm{ha}^{-1}$ over the control. At Boricha, bean biomass and/or grain yields due to inoculation were also statistically at the same level as the plot receiving synthetic N. Similarly, as the year 2015, bean inoculated with HAMBI3570 performed well in 2016, showing $6750 \mathrm{~kg} \mathrm{ha}^{-1}$ and $4250 \pm 289 \mathrm{~kg} \mathrm{ha}^{-1,}$ biomass and grain yields, respectively, which in terms of grain yield was $680 \mathrm{~kg} \mathrm{ha}^{-1}$ more than in the non-inoculated 307 control.

\section{[Table 3 near here]}

309 Depending on the years and/or the experimental sites, soybeans inoculated with rhizobial strains 310 produced higher or equivalent biomass and grain yield compared to the plots receiving synthetic 311 N. At the Halaba site in the dry year 2015, soybean inoculated with strain HAMBI3513 showed 
312 the highest biomass $\left(2600 \pm 57 \mathrm{~kg} \mathrm{ha}^{-1}\right)$, followed by HAMBI3520 and soybean receiving synthetic N. The rhizobial inoculants HAMBI3513, HAMBI520 and the commercial inoculant

314 LF were conducive to about $200 \mathrm{~kg} \mathrm{ha}^{-1}$ higher soybean gain yields (617 \pm 16 to $643 \pm 142 \mathrm{~kg}$

$315 \mathrm{ha}^{-1}$ ) over the non-inoculated control. The grain yield obtained from plot receiving synthetic $\mathrm{N}$ 316 was $613 \pm 81 \mathrm{~kg} \mathrm{ha}^{-1}$. In that year at Boricha, soybean inoculated with strains HAMBI513, 317 HAMBI3524 or the commercial inoculant LF showed significantly higher biomass (1260 \pm 17 318 to $\left.1397 \pm 26 \mathrm{~kg} \mathrm{ha}^{-1}\right)$ and grain yields $\left(427 \pm 20\right.$ to $\left.507 \pm 23 \mathrm{~kg} \mathrm{ha}^{-1}\right)$ compared to the other 319 treatments, the grain yields of these treatments being $100-180 \mathrm{~kg} \mathrm{ha}^{-1}$ higher than in the control.

At Halaba when the moisture condition was optimal in 2016, the strains HAMBI3513, HAMBI3524 and commercial inoculant LF gave higher biomass (13426 \pm 197 to $\left.13951 \pm 41 \mathrm{~kg} \mathrm{ha}^{-1}\right)$ and grain yields $\left(4525 \pm 241\right.$ to $\left.4966 \pm 47 \mathrm{~kg} \mathrm{ha}^{-1}\right)$ than the other treatments, the grain yields of these plots being $1430-1870 \mathrm{~kg} \mathrm{ha}^{-1}$ higher than in the noninoculated control. The biomass and grain yields obtained from soybean receiving synthetic $\mathrm{N}$ were $12738 \pm 487 \mathrm{~kg} \mathrm{ha}^{-1}$ and $3383 \pm 494 \mathrm{~kg} \mathrm{ha}^{-1}$ respectively. In the second year at Boricha, soybeans inoculated with strains HAMBI3513, HAMBI3520 and HAMBI3524 provided higher biomass (12222 \pm 147 to $\left.12778 \pm 111 \mathrm{~kg} \mathrm{ha}^{-1}\right)$ and grain yield $(5667 \pm 117$ to $6611 \pm 56 \mathrm{~kg} \mathrm{ha}$ ${ }^{1}$, the increase being $2220-3160 \mathrm{~kg} \mathrm{ha}^{-1}$ over the control), followed by soybean receiving synthetic $\mathrm{N}$ fertilizer (Table 4).

\section{Discussion}

334 Pulses are staple foods and important sources of protein in Ethiopia (Asfaw et al. 2009; Katungi et al. 2010). Pulse legumes are also used in cropping systems to improve soil fertility for subsequent crops (Bado et al. 2013; Zerihun and Haile 2017). Inoculation of pulses with 
superior $\mathrm{N}_{2}$-fixing rhizobia enhances food production as well as helps to reduce environmental impacts caused by synthetic $\mathrm{N}$-fertilizer.

In this work, the growth, and nodulation, SDW and total N contents of the pulses inoculated with rhizobial strains in the greenhouse were increased significantly over noninoculated control plants, confirming the establishment of effective $\mathrm{N}_{2}$-fixing symbiosis between the rhizobia and their host legume pulses. Subsequently, three effective $\mathrm{N}_{2}$-fixing rhizobial strains were tested in field conditions with bean and soybean plants. In the field, the growth of the inoculated pulses increased significantly compared with the non-inoculated controls. Inoculation gave equal to or higher biomass and yields than those of pulses receiving synthetic $\mathrm{N}$ fertilizer depending on the rhizobia strains and field sites, in accordance with previous findings (Solomon et al. 2012; Argaw and Muleta 2017).

The drought in 2015 caused major crop yield reduction in a large part of Ethiopia (AKLDP 2015; Philip et al. 2018). Likewise, in the first year of the field study, the plant growth was affected by drought stress. As a result, the mean nodule number, the biomass and yields of the pulses were significantly lower compared to the corresponding results in the second year, which was normal. According to Lodeiro et al. (2000), inoculated beans showed better tolerance and survival status as well as delayed leaf senescence during water deficits than bean provided with sufficient levels of synthetic $\mathrm{N}$ fertilizer. A finding in Egypt by Yanni et al. (2016) indicated that the symbiotic performance and productivity of beans inoculated with stress tolerant native rhizobia improved in moisture stressed field. In our study, beans and soybeans inoculated with elite rhizobial strains generally showed better tolerance to drought than plants receiving synthetic $\mathrm{N}$, which was expressed as delayed leaf senescence of the plants in the field. Access of synthetic $\mathrm{N}$ fertilizer by the legumes and the supply of nutrients via mineralization could be decreased due to the lack of enough moisture during drought. Consequently, plant growth and production would be affected negatively (Sardans et al. 2008). On other hand, the 
drought tolerance of pulses that obtain their N source via BNF can be enhanced by rhizobia 363 inoculation.

The higher nodule number obtained due to inoculation, regardless of the sites and years, over the non-inoculated controls and plots receiving synthetic $\mathrm{N}$ fertilizer, suggests that 366 the introduced inoculants were more competent than the background soil rhizobia to make 367 nodules in symbiosis with the host legumes. On the other hand, this result also suggests that the 368 population of rhizobia nodulating pulses occur in lower numbers in the field sites. Previous reports (Asad et al. 2004; Fatima et al. 2007; Assefa et al. 2017) indicate

370 that seeds per pod, pods per plant, plant height, and hundred seed weight of beans increased as 371 a result of rhizobia inoculation. According to other studies (Fageria and Santos 2008; Mulas et 372 al. 2015), these parameters were varied more depending on bean varieties and/or environmental 373 factors rather than by inoculation and synthetic $\mathrm{N}$ application. In our study, overall the 374 parameters were improved by rhizobial inoculation over the non-inoculated control or varied between treatments depending on locations and years or by their interaction (Table 3 and 4). inoculation, by which symbiotic performances and grain yield of beans improved. According to Abebe (2017), the yield and yield components of beans were significantly increased due to rhizobia inoculation. In our study, inoculation in general improved nodule numbers, and 380 biomass and grain yields of the pulse compared to the non-inoculated controls. However, there 381 was a disparity in biomass and grain yields of inoculated pulse depending on the strains and the 382 field sites (Table 3). This could be attributed to the differences in adaptability between strains 383 to different local conditions. The Boricha site is characterized by lower soil $\mathrm{pH}(6.4)$ compared 384 to the conditions at Halaba site ( $\mathrm{pH}$ 8). Strain HAMBI3570 seems to be better adapted to the 385 slightly acidic soils of the Boricha site, whereas strain HAMBI3562 performed better at the 386 Halaba site with the slightly alkaline condition (Table 2). Both in 2015 and 2016, beans 387 inoculated with strains HAMBI3562 and HAMBI3570 at Halaba and Boricha respectively gave 
the highest or equivalent biomass and grain yields compared to the other inoculants and synthetic $\mathrm{N}$ fertilizer. Thus, our result supports the need for location specific rhizobial inoculation, as was previously suggested by Argaw and Muleta (2017), based on their research conducted in eastern Ethiopia.

Soybean cultivation is relatively new in Ethiopia. Consequently, rhizobia nodulating soybean are not commonly isolated from the soils of Ethiopia, except in a few 394 successful studies (Aserse et al. 2012a; Muleta et al. 2017). Therefore, exotic and commercially available soybean-nodulating strains were tested in the field as inoculants and compared with native strains (Merkeb et al. 2016; Muleta et al. 2017). According to these studies, soybean yields were variable depending on the experimental locations. For example, significant increases in soybean yield components because of inoculation with strain TAL379 was reported by Solomon et al. (2012). On the contrary, in another investigation, soybean yield could not be improved by inoculation with this inoculant (Yoseph and Worku 2014). In our study, depending on the sites or growing seasons soybeans inoculated with the reference strains HAMBI3524 (obtained as TAL379), the commercial inoculant LF and the native HAMBI520, generally produced comparable or higher biomass and grain yields than soybean that received $\mathrm{N}$ fertilizer. However, inoculation with Ethiopian native strain HAMBI3513 gave consistently higher or comparable soybean biomass and grain yields than the plots received synthetic $\mathrm{N}$ fertilizer regardless of the locations and the test years.

\section{Conclusion}

408 Rhizobial inoculation improved plant drought tolerance, growth, and biomass and grain yield 409 of beans as well as soybeans. This suggests that the rhizobial strains are adapted to the local environmental conditions to form effective $\mathrm{N}_{2}$-fixing symbiosis with the respective hosts. The

411 results also show the benefit of rhizobia inoculation as an alternative to synthetic $\mathrm{N}$ application 412 for mitigating the soil fertility problems, contributing to the opportunities for smallholder 413 farmers to sustainably produce nutritious and protein-rich food. Even though soybean biomass 
414 and grain yields increased by inoculation with both the native and reference exotic rhizobial

415 strains, Ethiopian strain HAMBI3513 was the most consistent. Therefore, the local strain

416 HAMBI3513 for soybeans and Ethiopian strains HAMBI3562 and HAMBI3570 for beans,

417 could be selected as inoculants for areas having similar soil properties and climatic conditions

418 as the sites used in our study.

419 Acknowledgments

420 This research work was supported by the SOILMAN project funded by the Academy of Finland

421 (grant number 266563). The rhizobial inoculants were prepared by Finnish inoculant producing

422 company Elomestari Ltd. The authors are grateful to Mr. Daniel Richterich at Viikki plant

423 growth facility of the University of Helsinki, for providing greenhouse space used for this study.

424 Disclosure statement

425 No conflict of interest.

\section{References}

Abebe Z. 2017. On-farm yield variability and responses of common bean (Phaseolus vulgaris L.) varieties to rhizobium inoculation with inorganic fertilizer rates. J Anim Plant Sci. 32 (2):5120-5133.

AKLDP 2015. El Niño in Ethiopia: Analyzing the summer kiremt rains in 2015. The USAID Ethiopia Agriculture Knowledge, Learning, Documentation and Policy project in Ethiopia; Technical Brief December 2015. http://www.agri-learning-ethiopia.org/wpcontent/uploads/2016/01/AKLDP-El-Nino-Rains-Technical-Brief.pdf.

Argaw A, Muleta D. 2017. Effect of genotypes-Rhizobium environment interaction on nodulation and productivity of common bean (Phaseolus vulgaris L.) in eastern Ethiopia. 
Asad AS, Bano A, Farooq M, Aslam M, Afzal AB. 2004. Comparative study of the effects of biofertilizers on nodulation and yield characteristics of mung bean (Vigna radiata). Int $\mathbf{J}$ Agri Biol. 6(5):837-843.

Aserse AA, Räsänen LA, Aseffa F, Hailemariam A, Lindström K. 2012a. Phylogenetically diverse groups of Bradyrhizobium isolated from nodules of Crotalaria spp., Indigofera spp., Erythrina brucei and Glycine max growing in Ethiopia. Mol Phylogenet Evol. 65: 595-609.

Aserse AA, Räsänen LA, Assefa F, Hailemariam A, Lindström K. 2012b. Phylogeny and genetic diversity of native rhizobia nodulating common bean (Phaseolus vulgaris L.) in Ethiopia. Syst Appl Microbiol. 35 (2):120-31.

Asfaw A, Assefa T, Amsalu B, Negash K, Alemayehu F, Grum F. 2008. Adaptation and yield stability of small red bean elite lines in Ethiopia. Int J Plant Breed Genet. 2(2): 51-63.

Asfaw A, Blair MW, Almekinders C. 2009. Genetic diversity and population structure of common bean (Phaseolus vulgaris L.) landraces from the east Africa highlands. Theor Appl Genet. 120(1):1-12.

Assefa AM, Amsalu B, Tana T. 2017. Response of common Bean (Pharsalus vulgaris L.) cultivars to combined application of rhizobium and NP fertilizer at Melkassa, central Ethiopia. IJPSS. 14(1):1-10.

Bado BV, Cescas MP, Bationo A, Sedogo MP, Cescas MP, Traore T. 2013. Influence of legumes on nitrogen $(\mathrm{N})$ fertilizer recommendations for succeeding sorghum in the Guinea savannah of West Africa. Afr J Agric Res. 8:6416-6421.

Belay 1987. Progress and future soybean research in Ethiopia. Proceedings of the $19^{\text {th }}$ National Crop Conferences; April 22-26; Addis Ababa, Ethiopia. p. 252-265.

Cochrane L, Bekele YW. 2018. Average crop yield (2001-2017) in Ethiopia: Trends at national, regional and zonal levels. Data in Brief 16:1025-1033. 
Darkwa K, Ambachew D, Mohammed H, Asfaw A, Blair MW. 2016. Evaluation of common bean (Phaseolus vulgaris L.) genotypes for drought stress adaptation in Ethiopia. The Crop Journal 4:367-376.

Emishaw W. 2007. Comparision of the growth, photosynthesis, and transpiration of improved and local varieties of common bean (Phaseolus vulgaris L) [master's thesis]. Haramaya (Ethiopia): Haramaya University.

Fadong LI, Peifang L, Qiuying Z, Shuai S, Yunfeng Q, Congke G, Qian Z, Liang W, Balehegn M, Mojo D, et al. 2018. Understanding agriculture production and food security in Ethiopia from the perspective of China. J Resour Ecol. 9(3) 237-249.

Fageria NK, Santos AB. 2008. Yield physiology of dry bean. J Plant Nutr. 31:983-1004.

FAO 2014. World reference base for soil classification and mapping legend. An international soil classification system for naming the soils and creating legend for soil maps: World soil resources report 106. Rome, Italy.

Fatima Z, Muhammad Z, Chaudhary MF. 2007. Interactive effect of Rhizobium strains and P on soybean yield, nitrogen fixation and soil fertility. Pak J Bot. 39(1): 255-264.

Finnish Standards Association SFS. 2002a. Standard SFS-EN 13651. Soil improvers and growing media. Extraction of calcium chloride/DTPA (CAT) soluble nutrients.

Finnish Standards Association SFS. 2002b. Standard SFS-EN 13652. Soil improvers and growing media. Extraction of water soluble nutrients and elements.

Ganewo Z, Tefera T, Hirpa A. 2017. Determinants of varietal replacement of haricot bean by farmers in Boricha District, southern Ethiopia. JSD 5(1):14-20.

Getahun A, Tefera E. 2017. Soybean value chain assessment study in northwestern Ethiopia, Metekel Zone. AJAEES.14 (4):1-14.

Katungi E, Farrow A, Mutuoki T, Gebeyehu S, Karanja D, Alemayehu F, Sperling L, Beebe S, Rubyogo JC, Buruchara R. 2010. Improving common bean productivity: An analysis of 
socioeconomic factors in Ethiopia and Eastern Kenya. Baseline report tropical legumes II. CIAT. Cali, Colombia.

Lodeiro A, González P, Hernández A, Balagué L, Favelukes G. 2000. Comparison of drought tolerance in nitrogen-fixing and inorganic nitrogen-grown common beans. Plant Sci. $154: 31-41$

493

494

495

496

497

MARD 2013. Ministry of Agriculture and Rural Development, Addis Ababa, Ethiopia, 2013. Crop variety registration issue no.16, Crop development.

Merkeb F, Redi R, Gebremedhin W. 2016. Evaluation of different commercial rhizobial strains on soybean (Glycine max L.) yield at Pawe district, Northwestern Ethiopia. WSN 55:1526.

Mulas D, Seco V, Casquero PA, Velázquez E, González-Andrés F. 2015. Inoculation with indigenous Rhizobium strains increases yields of common bean (Phaseolus vulgaris L.) in northern Spain, although its efficiency is affected by the tillage system. Symbiosis 67:113-124.

Muleta D, Ryder MH, Denton MD. 2017. The potential for rhizobial inoculation to increase soybean grain yields on acid soils in Ethiopia. Soil Sci Plant Nutri. 63(5): 441-451.

Philip S, Kew SF, van Oldenborth GJ, Otto F, O’Keefe S, Haustein K, King A, Zegeye A, Eshetu Z, Hailemariam K, Singh R, Jjemba E, Funk C, Cullen H. 2018. Attribution analysis of the Ethiopian drought of 2015. Journal of Climate 31:2465-86.

Samago TY, Endalkachew WA, Dakora FD. 2017. Grain yield of common bean (Phaseolus vulgaris L.) varieties is markedly increased by rhizobial inoculation and phosphorus application in Ethiopia. Symbiosis 75:245-255.

Sardans J, Penuelas J, Estiarte M. 2008. Changes in soil enzymes related to C and N cycle and in soil $\mathrm{C}$ and $\mathrm{N}$ content under prolonged warming and drought in a Mediterranean shrub land. Appl Soil Ecol. 39: 223-235. 
Sinclair TR, Marrou H, Soltani A, Vadez V, Chandolu, KC. 2014. Soybean production potential in Africa. Global Food Security 3:31-40.

Solomon T, Pant LM, Angaw T. 2012. Effects of inoculation by Bradyrhizobium japonicum strains on nodulation, nitrogen fixation, and yield of soybean (Glycinemax L.Merill) varieties on nitisols of Bako, Western Ethiopia. ISRN Agronomy (ID 261475):1-8

Somasegaran P, Hoben HJ. 1994. Handbook for Rhizobia: methods in Legume-Rhizobium technology. Heidelberg, Germany: Springer.

Tarfasa S, Balana B.B, Tefera T, Woldeamanuel T, Moges A, Dinato M, Black H. 2018. Modeling smallholder farmers' preferences for soil management measures: A case study from south Ethiopia. Ecological Economics 145:410-419.

Tesfa A, Mekuriaw S. 2014. The effect of land degradation on farm size dynamics and croplivestock farming system in Ethiopia. OJSS. 4:1-5.

UNDP: human development reports. 1990 - 2018. Geneva: United Nations Development Programme [accessed 2019 March 20]. http://hdr.undp.org/en/2018-update.

van Reeuwijk, LP. (ed). 2002. Procedures for soil analysis. International Soil Reference and Information Centre. Technical Paper 9. 6th Ed.

Welteji D. 2018. A critical review of rural development policy of Ethiopia: access, utilization and coverage. Agric \& Food Secur. 7:55.

WFP: 2018 Global Report on Food Crises. 21 March 2018. Rome, Italy: World Food Programme; [accessed 2019 March 20]. https://www.wfp.org/content/global-reportfood-crises-2018.

Yanni Y, Zidanb M, Dazzoc F, Rizka R, Mehesena A, Abdelfattaha F, Elsadanya A. 2016. Enhanced symbiotic performance and productivity of drought stressed common bean after inoculation with tolerant native rhizobia in extensive fields. Agric Ecosyst Environ. 232:119-128. 
538 Yoseph T, Worku W. 2014. Effect of NP fertilizer rate and Bradyrhizobium inoculation on nodulaton, N-uptake and crude protein content of soybean (Glycine max L.) at Jinka, southern Ethiopia. Journal of Biology, Agriculture and Healthcare 4(6):49-54.

541 Zerihun A, Alemayo D, Wolde-Meskel E. 2015. On farm yield responses of soybean (Glycine $\max$ L.) to fertilizer sources under different soil acidity status in Gobu Sayo district, Western Ethiopia. J Agron.14: 30-36.

544 Zerihun A, Haile S. 2017. The Effect of organic and inorganic fertilizers on the yield of two contrasting soybean varieties and residual nutrient effects on a subsequent finger millet crop. Agronomy 7:42 
549 Table 1. Shoot dry weight (SDW), and C and N contents (means of three replicates \pm SE) of 550 inoculated common bean and soybean plants grown in the greenhouse

\begin{tabular}{|c|c|c|c|c|}
\hline HAMBI code & Species & $\begin{array}{l}\text { SDW }(g) / \\
\text { plant }\end{array}$ & $\begin{array}{l}\mathrm{N}(\mathrm{g}) / \\
\text { plant }\end{array}$ & $\begin{array}{l}\mathrm{C}(\mathrm{g}) / \\
\text { plant }\end{array}$ \\
\hline \multicolumn{5}{|c|}{ Common bean plant } \\
\hline HAMBI3562* & Rhizobium phaseoli HBR10 & $19.3 \pm 1 \mathrm{a}$ & $0.47 \pm 0.01 \mathrm{a}$ & $7.41 \pm 0.4 \mathrm{a}$ \\
\hline HAMBI3570* & R. phaseoli HBR53 & $17.9 \pm 2 \mathrm{a}$ & $0.46 \pm 0.01 \mathrm{a}$ & $6.66 \pm 0.8 \mathrm{a}$ \\
\hline HAMBI3556* & R. etli HBR5 & $18.3 \pm 1 \mathrm{a}$ & $0.45 \pm 0.01 \mathrm{a}$ & $7.00 \pm 0.4 \mathrm{a}$ \\
\hline HAMBI3573 & R. phaseoli HBR79 & $17.90 \pm 0.2 \mathrm{a}$ & $0.45 \pm 0.02 \mathrm{a}$ & $6.84 \pm 0.1 \mathrm{a}$ \\
\hline HAMBI3565 & R. leguminosarum HBR42 & $19.0 \pm 0.4 \mathrm{a}$ & $0.44 \pm 0.01 \mathrm{a}$ & $7.25 \pm 0.2 \mathrm{a}$ \\
\hline HAMBI3542 & R. phaseoli HBR1 & $16.2 \pm 1 \mathrm{ab}$ & $0.42 \pm 0.02 \mathrm{a}$ & $6.26 \pm 0.3 \mathrm{a}$ \\
\hline HAMBI3547 & R. phaseoli HRB18 & $15.5 \pm 1.1 b$ & $0.36 \pm 0.03 \mathrm{ab}$ & $5.93 \pm 0.4 a$ \\
\hline HAMBI3560 & R. etli HBR24 & $15.2 \pm 1.6 b$ & $0.33 \pm 0.04 \mathrm{~b}$ & $5.73 \pm 0.6 \mathrm{a}$ \\
\hline HAMBI3557 & R. leucaenae HBR12 & $14.1 \pm 1 b$ & $0.33 \pm 0.02 b$ & $5.31 \pm 0.3 \mathrm{ab}$ \\
\hline HAMBI3559 & R. etli HBR23 & $18.1 \pm 1.4 \mathrm{a}$ & $0.31 \pm 0.03 b$ & $6.87 \pm 0.8 \mathrm{a}$ \\
\hline HAMBI3563 & R. etli HBR31 & $15.4 \pm 1.4 b$ & $0.27 \pm 0.02 b c$ & $5.77 \pm 0.5 \mathrm{ab}$ \\
\hline HAMBI3543 & R. etli HBR3 & $13.7 \pm 0.8 \mathrm{bc}$ & $0.26 \pm 0.02 b c$ & $5.11 \pm 0.3 \mathrm{ab}$ \\
\hline HAMBI3550 & R. etli HBR26 & $15.6 \pm 1.4 \mathrm{~b}$ & $0.23 \pm 0.02 \mathrm{c}$ & $5.89 \pm 0.5 \mathrm{a}$ \\
\hline HAMBI3558 & R. leguminosarum HBR22 & $14.2 \pm 0.8 b$ & $0.22 \pm 0.01 \mathrm{c}$ & $5.35 \pm 0.3 \mathrm{ab}$ \\
\hline HAMBI3553 & R. etli HBR19 & $10.6 \pm 1.1 \mathrm{c}$ & $0.19 \pm 0.02 \mathrm{c}$ & $3.95 \pm 0.4 b$ \\
\hline $\begin{array}{l}\text { Non-inoculated } \\
\text { control beans }\end{array}$ & & $9.0 \pm 1.2 \mathrm{~cd}$ & $0.18 \pm 0.02 \mathrm{~cd}$ & $3.48 \pm 0.4 b$ \\
\hline HAMBI3549 & R. giardinii HBR21 & $8.3+1 \mathrm{~cd}$ & $0.11 \pm 0.01 \mathrm{~cd}$ & $3.02 \pm 0.4 \mathrm{~b}$ \\
\hline $\mathrm{p}$-values & Treatments & 0.00 & 0.00 & 0.00 \\
\hline Variance & & 13.05 & 0.014 & 1.985 \\
\hline \multicolumn{5}{|l|}{ Soybean plant } \\
\hline HAMBI3524* & $\begin{array}{l}\text { Bradyrhizobium } \\
\text { japonicum TAL379 }\end{array}$ & $16.7 \pm 0.6 \mathrm{a}$ & $0.42 \pm 0.02 \mathrm{a}$ & $6.82 \pm 0.2 \mathrm{a}$ \\
\hline HAMBI3513* & B. elkanii SBR2B & $17.2 \pm 0.2 \mathrm{a}$ & $0.36 \pm 0.01 b$ & $6.97 \pm 0.1 \mathrm{a}$ \\
\hline HAMBI3520* & B. elkanii SBR8B & $17.5 \pm 0.2 \mathrm{a}$ & $0.35 \pm 0.01 b$ & $7.10 \pm 0.1 \mathrm{a}$ \\
\hline HAMBI3516 & Bradyrhizobium sp. SBR6 & $15.5 \pm 1.3 \mathrm{ab}$ & $0.34 \pm 0.03 b$ & $6.26 \pm 0.6 \mathrm{ab}$ \\
\hline HAMBI3515 & B. elkanii SBR5B & $16.1 \pm 0.2 \mathrm{ab}$ & $0.33 \pm 0.01 b$ & $6.51 \pm 0.1 \mathrm{ab}$ \\
\hline HAMBI3517 & B. elkanii SBR7A & $16.3 \pm 0.6 \mathrm{ab}$ & $0.32 \pm 0.01 b$ & $6.58 \pm 0.2 \mathrm{ab}$ \\
\hline HAMBI3525 & B. genosp. SA2 strain SBR1B & $16.2 \pm 0.6 \mathrm{ab}$ & $0.25 \pm 0.01 \mathrm{c}$ & $6.15 \pm 0.2 \mathrm{ab}$ \\
\hline HAMBI3518 & B. elkanii SBR7B & $16.1 \pm 0.6 \mathrm{ab}$ & $0.16 \pm 0.01 \mathrm{~d}$ & $5.46 \pm 0.2 b$ \\
\hline $\begin{array}{l}\text { Non-inoculated } \\
\text { control soybeans }\end{array}$ & & $14.5 \pm 0.3 b$ & $0.14 \pm 0.00 \mathrm{~d}$ & $5.28 \pm 0.1 \mathrm{~b}$ \\
\hline $\begin{array}{l}\text { p-values } \\
\text { Variance }\end{array}$ & Treatments & $\begin{array}{l}0.05 \\
1.51\end{array}$ & $\begin{array}{l}0.02 \\
0.01\end{array}$ & $\begin{array}{l}0.06 \\
0.26\end{array}$ \\
\hline
\end{tabular}

*Top three strains selected for field trials.

Means with the same letter in the same column show not significant difference between treatments at $p \leq 0.05$ by 
Table 2. Soil properties of the experimental sites

\begin{tabular}{|c|c|c|c|c|c|c|c|c|c|c|c|c|c|c|c|c|}
\hline & Clay & Silt & Sand & $\begin{array}{l}\text { Soil } \\
\text { type }\end{array}$ & $\mathrm{C}$ tot & $\mathrm{N}$ tot & $\begin{array}{l}\mathrm{pH} \\
\left(\mathrm{H}_{2} \mathrm{O}\right)\end{array}$ & $\mathrm{EC}$ & $\mathrm{Ca}$ & $\mathrm{K}$ & $\mathrm{Mg}$ & $\mathrm{Na}$ & TA & $\mathrm{CEC}_{\mathrm{pot}}$ & $\mathrm{BS}$ & P Olsen \\
\hline & $\%$ & $\%$ & $\%$ & & $\%$ & $\%$ & & $\begin{array}{l}\mu \mathrm{SS} \\
\mathrm{cm}^{-1}\end{array}$ & & & & $\mathrm{cmol}_{\mathrm{c}} \mathrm{kg}^{-1}$ & & & $\%$ & $\mathrm{mg} \mathrm{kg}^{-1}$ \\
\hline $\begin{array}{l}\text { Halaba soybean } \\
\text { topsoil }\end{array}$ & 23 & 44 & 33 & Loam & 1.5 & 0.12 & 7.9 & 219 & 17.9 & 2.5 & 2.2 & 0.4 & 0 & 23 & 100 & 1.5 \\
\hline $\begin{array}{l}\text { Halaba soybean } \\
\text { subsoil }\end{array}$ & & & & & 1.3 & 0.09 & 7.9 & 257 & 22.2 & 2.5 & 2.8 & 2.0 & 0 & 29.5 & 100 & \\
\hline $\begin{array}{l}\text { Halaba common } \\
\text { bean topsoil }\end{array}$ & 21 & 45 & 34 & Loam & 1.4 & 0.10 & 8.1 & 217 & 17.8 & 2.5 & 2.3 & 0.2 & 0 & 22.7 & 100 & 2.0 \\
\hline $\begin{array}{l}\text { Halaba common } \\
\text { bean subsoil }\end{array}$ & & & & & 1.1 & 0.07 & 7.7 & 137 & 12.2 & 3.0 & 3.3 & 0.8 & 0.9 & 20.2 & 96 & \\
\hline $\begin{array}{l}\text { Borincha } \\
\text { topsoil }\end{array}$ & 26 & 45 & 29 & Loam & 1.8 & 0.13 & 6.4 & 126 & 13.0 & 1.1 & 1.8 & 0.1 & 3.0 & 19.0 & 84 & 5.5 \\
\hline $\begin{array}{l}\text { Borincha } \\
\text { subsoil }\end{array}$ & & & & & 1.1 & 0.07 & 6.9 & 69 & 10.2 & 0.8 & 2.4 & 0.3 & 2.1 & 15.8 & 87 & \\
\hline
\end{tabular}

EC: Electrical conductivity of soil extract (1:2.5), TA: Titratable acidity, BS: Base saturation 
Table 3. Effect of rhizobia inoculation on biomass yield and yield parameters (means of three replicates $\pm \mathrm{SE}$ ) of common beans in the field conditions.

\begin{tabular}{|c|c|c|c|c|c|c|c|c|c|}
\hline Year & Site & Treatment & $\begin{array}{l}\text { Biomass } \\
\text { yield } \\
\left(\mathrm{kg} \mathrm{ha}^{-1}\right) \\
\end{array}$ & $\begin{array}{l}\text { Grain yield } \\
\left(\mathrm{kg} \mathrm{ha}^{-1}\right)\end{array}$ & $\begin{array}{l}\text { Nodule } \\
\text { number }\end{array}$ & $\begin{array}{l}\text { Plant } \\
\text { height } \\
(\mathrm{cm}) \\
\end{array}$ & $\begin{array}{l}\text { Seed/ } \\
\text { pod }\end{array}$ & $\begin{array}{l}\text { Pod/ } \\
\text { plant }\end{array}$ & $\begin{array}{l}\text { Hundred } \\
\text { seed } \\
\text { weight (g) } \\
\end{array}$ \\
\hline \multirow[t]{12}{*}{2015} & \multirow[t]{6}{*}{ BORICHA } & EAL428 & $760 \pm 23 c$ & $476 \pm 58 c$ & $14 \pm 3 a$ & $39 \pm 2 a$ & $4 \pm 0.3 a$ & $10 \pm 0.3 b$ & $24 \pm 3 a$ \\
\hline & & HAMBI3562 & $870 \pm 358 b c$ & $537 \pm 3 b c$ & $17 \pm 3 a$ & $39 \pm 2 a$ & $4 \pm 0.3 a$ & $14 \pm 3 a$ & $26 \pm 2 a$ \\
\hline & & HAMBI3570 & $1240 \pm 788 a$ & $640 \pm 35 \mathrm{ab}$ & $14 \pm 2 \mathrm{a}$ & $38 \pm 3 a$ & $4 \pm 1 \mathrm{a}$ & $9 \pm 1 b$ & $24 \pm 2 a$ \\
\hline & & HAMBI3556 & $927 \pm 15 b c$ & $510 \pm 29 b c$ & $13 \pm 2 \mathrm{a}$ & $37 \pm 1 \mathrm{a}$ & $5 \pm 0.3 a$ & $\begin{array}{l}15 \pm \\
0.2 \mathrm{a}\end{array}$ & $26 \pm 1 \mathrm{a}$ \\
\hline & & $\mathrm{NF}$ & $1137 \pm 199 \mathrm{ab}$ & $683 \pm 72 a$ & $8 \pm 1 b$ & $35 \pm 5 a$ & $4 \pm 1 a$ & $10 \pm 3 b$ & $25 \pm 2 a$ \\
\hline & & NoNF & $340 \pm 0 d$ & $140 \pm 0 \mathrm{~d}$ & $8 \pm 2 b$ & $32 \pm 2 a$ & $4 \pm 1 a$ & $8 \pm 2 b$ & $19 \pm 1 b$ \\
\hline & \multirow[t]{6}{*}{ HALABA } & EAL428 & $1587 \pm 143 b c$ & $810 \pm 69 \mathrm{~cd}$ & $36 \pm 11 b$ & $37 \pm 1 a$ & $4 \pm 0.3 a$ & $7 \pm 1 \mathrm{a}$ & $24 \pm 1 a$ \\
\hline & & HAMBI3562 & $3013 \pm 355 a$ & $1500 \pm 81 a$ & $61 \pm 21 a b$ & $35 \pm 3 a$ & $4 \pm 0.3 a$ & $9 \pm 2 a$ & $26 \pm 1 \mathrm{a}$ \\
\hline & & HAMBI3570 & $1910 \pm 46 b c$ & $1013 \pm 32 b c$ & $80 \pm 1 \mathrm{a}$ & $35 \pm 2 a$ & $4 \pm 0.1 \mathrm{a}$ & $10 \pm 2 \mathrm{a}$ & $24 \pm 1 a$ \\
\hline & & HAMBI3556 & $1546 \pm 9 b c$ & $803 \pm 113 \mathrm{~cd}$ & $59 \pm 5 a b$ & $36 \pm 5 a$ & $3 \pm 0.1 \mathrm{a}$ & $9 \pm 1 \mathrm{a}$ & $26 \pm 2 a$ \\
\hline & & $\mathrm{NF}$ & $2020 \pm 69 b$ & $1117 \pm 61 b$ & $27 \pm 2 b$ & $39 \pm 3 a$ & $4 \pm 0.3 a$ & $12 \pm 1 a$ & $25 \pm 0 \mathrm{a}$ \\
\hline & & NoNF & $1423 \pm 87 c$ & $653 \pm 22 d$ & $23 \pm 3 b$ & $29 \pm 1 b$ & $3 \pm 0.4 a$ & $8 \pm 2 a$ & $20 \pm 2 b$ \\
\hline \multirow[t]{20}{*}{2016} & \multirow[t]{6}{*}{ BORICHA } & EAL428 & $6523 \pm 416 a b$ & $3483 \pm 665 b$ & $29 \pm 5 a b$ & $38 \pm 2 \mathrm{a}$ & $5 \pm 1 \mathrm{a}$ & $17 \pm 0.3 \mathrm{a}$ & $24 \pm 1 a$ \\
\hline & & HAMBI3562 & $6517 \pm 546 a b$ & $4026 \pm 507 a$ & $42 \pm 4 a$ & $54 \pm 3 a$ & $5 \pm 1.5 \mathrm{a}$ & $19 \pm 0.2 \mathrm{a}$ & $24 \pm 1 a$ \\
\hline & & HAMBI3570 & $6750 \pm 0 \mathrm{a}$ & $4250 \pm 289 a$ & $23 \pm 5 a b$ & $34 \pm 3 a$ & $7 \pm 1 \mathrm{a}$ & $16 \pm 1 \mathrm{a}$ & $24 \pm 1 a$ \\
\hline & & HAMBI3556 & $6292 \pm 109 \mathrm{ab}$ & $4080 \pm 72 \mathrm{a}$ & $28 \pm 9 a b$ & $35 \pm 1 \mathrm{a}$ & $5 \pm 2 a$ & $18 \pm 0.3 \mathrm{a}$ & $24 \pm 3 a$ \\
\hline & & $\mathrm{NF}$ & $6917 \pm 546 a$ & $4333 \pm 464 a$ & $16 \pm 4 b$ & $35 \pm 3 a$ & $4 \pm 1 \mathrm{a}$ & $23 \pm 0.4 a$ & $26 \pm 0 \mathrm{a}$ \\
\hline & & NoNF & $5093 \pm 535 c$ & $3570 \pm 101 b$ & $13 \pm 3 b$ & $28 \pm 3 b$ & $4 \pm 2 a$ & $18 \pm 0.2 \mathrm{a}$ & $23 \pm 2 a$ \\
\hline & \multirow[t]{6}{*}{ HALABA } & EAL428 & $6273 \pm 1040 a b$ & $4141 \pm 1000 a$ & $31 \pm 6 a b$ & $47 \pm 9 \mathrm{ab}$ & $5 \pm 0.2 \mathrm{a}$ & $11 \pm 3.2 \mathrm{a}$ & $24 \pm 1 \mathrm{a}$ \\
\hline & & HAMBI3562 & $7022 \pm 130 \mathrm{a}$ & $4360 \pm 81 \mathrm{a}$ & $41 \pm 4 a$ & $54 \pm 11 a$ & $5 \pm 1.1 \mathrm{a}$ & $10 \pm 9 a$ & $25 \pm 2 \mathrm{a}$ \\
\hline & & HAMBI3570 & $5210 \pm 644 b$ & $3296 \pm 637 \mathrm{ab}$ & $26 \pm 7 b$ & $34 \pm 2 b$ & $6 \pm 2 a$ & $9 \pm 4 a$ & $24 \pm 1 a$ \\
\hline & & НАМВI3556 & $6050 \pm 635 \mathrm{ab}$ & $4608 \pm 160 a$ & $37 \pm 14 \mathrm{ab}$ & $35 \pm 3 b$ & $5 \pm 1 \mathrm{a}$ & $10 \pm 3 a$ & $25 \pm 1 \mathrm{a}$ \\
\hline & & $\mathrm{NF}$ & $7175 \pm 812 \mathrm{a}$ & $5064 \pm 1569 a$ & $22 \pm 3 b$ & $45 \pm 1 \mathrm{ab}$ & $4 \pm 1 \mathrm{a}$ & $13 \pm 13 a$ & $24 \pm 0 \mathrm{a}$ \\
\hline & & NoNF & $5243 \pm 1007 b$ & $2793 \pm 660 b$ & $18 \pm 3 b$ & $37 \pm 5 b$ & $5 \pm 2 a$ & $10 \pm 2.4 \mathrm{a}$ & $23 \pm 1 \mathrm{a}$ \\
\hline & \multirow[t]{7}{*}{ p-values } & Location & 0.08 & 0.26 & $0 *$ & 0.06 & $0 *$ & $0 *$ & 0.98 \\
\hline & & Treatment & $0.03 *$ & 0.36 & $0 *$ & $0.01 *$ & $0^{*}$ & $0.01 *$ & $0.01 *$ \\
\hline & & year & $0 *$ & $0 *$ & 0.31 & 0.15 & $0 *$ & $0 *$ & 0.15 \\
\hline & & $\begin{array}{l}\text { Location } \times \\
\text { Treatment }\end{array}$ & 0.36 & 0.84 & 0.11 & 0.58 & 0.35 & $0.02 *$ & 0.8 \\
\hline & & Year $\times$ Location & $0.01 *$ & 0.49 & $0 *$ & $0.01 *$ & $0^{*}$ & $0^{*}$ & 0.17 \\
\hline & & Year $\times$ Treatment & 0.63 & 0.85 & 0.1 & 0.47 & $0 *$ & 0.11 & 0.2 \\
\hline & & $\begin{array}{l}\text { Year } \times \text { Location } \times \\
\text { Treatment }\end{array}$ & 0.94 & 0.87 & 0.09 & 0.45 & 0.67 & $0.02 *$ & 0.77 \\
\hline & Variance & & 7127704.813 & 3760474.637 & 414.089 & 58.443 & 37.698 & 545.668 & \\
\hline
\end{tabular}

* The mean difference is significant at $\mathrm{p} \leq 0.05$ level. Means with the same letter show not significant difference between treatments at $\mathrm{p} \leq 0.05$, when it is calculated for each site and for each year separately and the different letters indicate presence of significant differences.

SE, standard error; NF, nitrogen fertilizer; NoNF, no nitrogen fertilizer and rhizobia application, non-inoculated control. 
Table 4. Effect of rhizobia inoculation on biomass, yield and yield parameters (means of three replicates \pm SE) of soybean in the field conditions.

\begin{tabular}{|c|c|c|c|c|c|c|c|c|c|}
\hline Year & Site & Treatment & $\begin{array}{l}\text { Biomass } \\
\text { Yield } \\
\left(\mathrm{kg} \mathrm{ha}^{-1}\right) \\
\end{array}$ & $\begin{array}{l}\text { Grain } \\
\text { Yield } \\
\left(\mathrm{kg} \mathrm{ha}^{-1}\right) \\
\end{array}$ & $\begin{array}{l}\text { Nodule } \\
\text { number }\end{array}$ & $\begin{array}{l}\text { Plant } \\
\text { height } \\
\text { (cm) }\end{array}$ & $\begin{array}{l}\text { Seed/ } \\
\text { pod }\end{array}$ & $\begin{array}{l}\text { Pod/ } \\
\text { plant }\end{array}$ & $\begin{array}{l}\text { Hundred } \\
\text { seeds } \\
\text { weight (g) }\end{array}$ \\
\hline \multirow{12}{*}{2015} & \multirow{6}{*}{ BORICHA } & LF & $1397 \pm 26 a$ & $487 \pm 38 \mathrm{ab}$ & $5 \pm 1 b c$ & $34 \pm 5 a$ & $2 \pm 0.2 \mathrm{a}$ & $27 \pm 10 b$ & $12 \pm 1 \mathrm{a}$ \\
\hline & & HAMBI3513 & $1260 \pm 17 a$ & $427 \pm 20 \mathrm{ab}$ & $11 \pm 1 \mathrm{a}$ & $34 \pm 7 a$ & $3 \pm 0.2 \mathrm{a}$ & $27 \pm 11 b$ & $15 \pm 4 a$ \\
\hline & & HAMBI3520 & $853 \pm 66 c$ & $347 \pm 18 \mathrm{c}$ & $13 \pm 5 a$ & $30 \pm 2 a$ & $2 \pm 0.1 \mathrm{a}$ & $18 \pm 5 b$ & $15 \pm 2 \mathrm{a}$ \\
\hline & & HAMBI3524 & $1393 \pm 43 a$ & $507 \pm 23 a$ & $6 \pm 0 b c$ & $38 \pm 6 a$ & $2 \pm 0.2 \mathrm{a}$ & $34 \pm 5 a$ & $13 \pm 1 \mathrm{a}$ \\
\hline & & $\mathrm{NF}$ & $1090 \pm 55 b$ & $370 \pm 10 c$ & $1 \pm 0 \mathrm{c}$ & $35 \pm 3 a$ & $2 \pm 0.1 \mathrm{a}$ & $23 \pm 9 b$ & $18 \pm 5 a$ \\
\hline & & NoNF & $860 \pm 40 c$ & $323 \pm 3 c$ & $1 \pm 0 \mathrm{c}$ & $31 \pm 4 a$ & $2 \pm 0.2 \mathrm{a}$ & $27 \pm 4 b$ & $13 \pm 2 \mathrm{a}$ \\
\hline & \multirow[t]{6}{*}{ HALABA } & $\mathrm{LF}$ & $1767 \pm 88 b$ & $630 \pm 139 a$ & $18 \pm 8 b c$ & $32 \pm 1 \mathrm{a}$ & $2 \pm 0 \mathrm{a}$ & $28 \pm 6 a$ & $16 \pm 0.2 \mathrm{a}$ \\
\hline & & HAMBI3513 & $2600 \pm 57 a$ & $617 \pm 16 \mathrm{a}$ & $75 \pm 4 a$ & $32 \pm 1 \mathrm{a}$ & $3 \pm 0.1 \mathrm{a}$ & $37 \pm 3 a$ & $15 \pm 1 \mathrm{a}$ \\
\hline & & HAMBI520 & $2100 \pm 208 \mathrm{ab}$ & $643 \pm 142 a$ & $42 \pm 7 \mathrm{ab}$ & $38 \pm 3 a$ & $2 \pm 1 \mathrm{a}$ & $48 \pm 5 a$ & $17 \pm 1 \mathrm{a}$ \\
\hline & & НАМВI3524 & $1777 \pm 412 b$ & $533 \pm 110 a b$ & $15 \pm 5 b c$ & $38 \pm 1 \mathrm{a}$ & $2 \pm 0.2 \mathrm{a}$ & $46 \pm 6 a$ & $16 \pm 1 \mathrm{a}$ \\
\hline & & $\mathrm{NF}$ & $1933 \pm 145 a b$ & $613 \pm 81 a$ & $6 \pm 3 c$ & $34 \pm 4 a$ & $2 \pm 0.1 \mathrm{a}$ & $43 \pm 12 a$ & $17 \pm 1 \mathrm{a}$ \\
\hline & & NoNF & $1373 \pm 27 b$ & $417 \pm 34 b$ & $2 \pm 0 \mathrm{c}$ & $32 \pm 2 \mathrm{a}$ & $2 \pm 0.2 \mathrm{a}$ & $40 \pm 6 a$ & $15 \pm 0.4 \mathrm{a}$ \\
\hline \multirow[t]{20}{*}{2016} & \multirow[t]{6}{*}{ BORICHA } & LF & $7778 \pm 55 b$ & $3611 \pm 73 b$ & $8 \pm 2 b c$ & $42 \pm 2 a$ & $2 \pm 1 \mathrm{a}$ & $81 \pm 18 a$ & $12 \pm 1 \mathrm{a}$ \\
\hline & & НАMBI3513 & $12222 \pm 147 \mathrm{a}$ & $6222 \pm 62 a$ & $32 \pm 8 \mathrm{a}$ & $40 \pm 4 a$ & $3 \pm 1 \mathrm{a}$ & $67 \pm 13 a b c$ & $15 \pm 3 a$ \\
\hline & & НАМВI3520 & $12778 \pm 111 \mathrm{a}$ & $6611 \pm 56 a$ & $37 \pm 4 a$ & $38 \pm 7 a$ & $2 \pm 0.3 \mathrm{a}$ & $92 \pm 2 \mathrm{a}$ & $15 \pm 2 \mathrm{a}$ \\
\hline & & HAMBI3524 & $12222 \pm 241 \mathrm{a}$ & $5667 \pm 117 \mathrm{ab}$ & $25 \pm 6 a b$ & $40 \pm 1 \mathrm{a}$ & $3 \pm 0.1 \mathrm{a}$ & $60 \pm 2 b c$ & $13 \pm 1 \mathrm{a}$ \\
\hline & & NF & $9999 \pm 96 \mathrm{ab}$ & $5278 \pm 100 \mathrm{ab}$ & $1 \pm 0 \mathrm{c}$ & $41 \pm 2 \mathrm{a}$ & $2 \pm 0.3 a$ & $71 \pm 10 \mathrm{ab}$ & $18 \pm 5 a$ \\
\hline & & NoNF & $8056 \pm 73 b$ & $3444 \pm 55 b$ & $1 \pm 1 \mathrm{c}$ & $38 \pm 4 a$ & $3 \pm 1 \mathrm{a}$ & $48 \pm 7 c$ & $13 \pm 1 \mathrm{a}$ \\
\hline & \multirow[t]{6}{*}{ HALABA } & $\mathrm{LF}$ & $13426 \pm 197 a$ & $4525 \pm 241 \mathrm{a}$ & $52 \pm 18 \mathrm{ab}$ & $43 \pm 4 a$ & $3 \pm 0.2 \mathrm{a}$ & $14 \pm 1 \mathrm{a}$ & $13 \pm 0.2 \mathrm{a}$ \\
\hline & & НАМВI3513 & $13951 \pm 41 \mathrm{a}$ & $4966 \pm 47 a$ & $86 \pm 26 a$ & $38 \pm 1 \mathrm{a}$ & $3 \pm 0.3 \mathrm{a}$ & $16 \pm 2 a$ & $14 \pm 1 \mathrm{a}$ \\
\hline & & HAMBI3520 & $12680 \pm 113 \mathrm{ab}$ & $3094 \pm 563 b$ & $56 \pm 7 \mathrm{ab}$ & $41 \pm 3 a$ & $3 \pm 0.2 \mathrm{a}$ & $17 \pm 2 \mathrm{a}$ & $13 \pm 0.4 a$ \\
\hline & & HAMBI3524 & $13782 \pm 54 a$ & $4574 \pm 78 \mathrm{a}$ & $84 \pm 17 a$ & $38 \pm 2 \mathrm{a}$ & $3 \pm 0.3 a$ & $15 \pm 1 \mathrm{a}$ & $15 \pm 1 \mathrm{a}$ \\
\hline & & $\mathrm{NF}$ & $12738 \pm 487 a b$ & $3383 \pm 494 b$ & $1 \pm 0 \mathrm{c}$ & $42 \pm 1 \mathrm{a}$ & $3 \pm 0.1 \mathrm{a}$ & $16 \pm 2 \mathrm{a}$ & $15 \pm 0.3 \mathrm{a}$ \\
\hline & & NoNF & $10450 \pm 1582 b$ & $3094 \pm 281 b$ & $1 \pm 0 \mathrm{c}$ & $41 \pm 2 \mathrm{a}$ & $3 \pm 0.2 \mathrm{a}$ & $19 \pm 3 a$ & $13 \pm 1 \mathrm{a}$ \\
\hline & \multirow[t]{7}{*}{ p-values } & Location & $0.00^{*}$ & $0.00 *$ & $0.00 *$ & 0.51 & $0.01 *$ & $0.00^{*}$ & 0.69 \\
\hline & & Treatment & $0.002 *$ & $0.03 *$ & $0.00 *$ & 0.82 & 0.18 & 0.55 & 0.07 \\
\hline & & year & $0.00^{*}$ & $0.00 *$ & $0.00 *$ & $0.00^{*}$ & $0.00 *$ & $0.00 *$ & 0.08 \\
\hline & & $\begin{array}{l}\text { Location } \times \\
\text { Treatment }\end{array}$ & 0.199 & $0.04 *$ & $0.01 *$ & 0.61 & 0.73 & 0.29 & 0.2 \\
\hline & & Year x Location & $0.01 *$ & $0.00 *$ & 0.35 & 0.98 & 0.45 & $0.00 *$ & 0.08 \\
\hline & & $\begin{array}{c}\text { Year } \times \\
\text { Treatment }\end{array}$ & $0.04 *$ & 0.07 & 0.11 & 0.56 & 0.85 & 0.12 & 0.99 \\
\hline & & $\begin{array}{c}\text { Year } \times \text { Location } \\
\times \text { Treatment }\end{array}$ & $0.05^{*}$ & $0.02 *$ & 0.4 & 0.94 & 0.62 & 0.09 & 0.99 \\
\hline & Variance & & 30255325.13 & 5389561.33 & 1065.26 & 35.43 & 0.57 & 593.5 & 9.16 \\
\hline
\end{tabular}

*The mean difference is significant at $\mathrm{p} \leq 0.05$ level. Means with the same letter show not significant difference between treatments at $\mathrm{p} \leq 0.05$, when it is calculated for each site and for each year separately and the different letters indicate presence of significant differences.

SE, standard error; NF, nitrogen fertilizer; NoNF, no nitrogen fertilizer and rhizobia application, non-inoculated control. 